\title{
Sandflies (Diptera: Psychodidae) in an urban area of Northeastern Brazil
}

\author{
Maria Claudia Ribeiro Agra ${ }^{[1],[2],}$, Pietra Lemos Costa ${ }^{[2]}$, Anderson Enio Silva Duque ${ }^{[2],}$ \\ Efraim Naftali Lopes Soares ${ }^{[3]}$, Leucio Câmara Alves ${ }^{[4]}$, \\ Rafael Antonio Nascimento Ramos ${ }^{[5]}$ and Gílcia Aparecida de Carvalho ${ }^{[5]}$
}

\begin{abstract}
[1]. Programa de Pós-Graduação Stricto Sensu em Ciência Animal Tropical, Universidade Federal Rural de Pernambuco, Recife, Pernambuco, Brasil. [2]. Gerência de Vigilância em Saúde, Secretaria Municipal de Saúde de Caruaru, Caruaru, Pernambuco, Brasil. [3]. IV Gerência Regional de Saúde, Secretaria Estadual de Saúde, Recife, Pernambuco, Brasil. [4]. Departamento de Medicina Veterinária, Universidade Federal Rural de Pernambuco, Recife, Pernambuco, Brasil. [5]. Unidade Acadêmica de Garanhuns, Universidade Federal Rural de Pernambuco, Garanhuns, Pernambuco, Brasil.
\end{abstract}

\begin{abstract}
Introduction: The sandfly fauna is well studied globally. In Brazil, sandfly fauna is very diverse in the Northeast region, especially in states such as Maranhão, Ceará, and Bahia. However, in the State of Pernambuco, the distribution of these insects is still not well known. Therefore, the objective of this study was to identify the different species that constitute the sandfly fauna in an urban area in the Northeast region of Brazil, where an outbreak of visceral leishmaniasis (VL) was recently reported. Methods: The sandflies were collected from an urban area endemic for VL, at five collection points. The collection of samples was carried out from November 2014 to December 2015, using CDC light traps installed in intradomiciliary and peridomiciliary fashion. Results: The collected sandflies $(\mathrm{n}=297)$ belonged to eight species: Lutzomyia lenti, Lutzomyia longipalpis, Lutzomyia sallesi, Lutzomyia migonei, Lutzomyia walkeri, Lutzomyia capixaba, Lutzomyia carmelinoi, and Lutzomyia whitmani. Most of the specimens collected were peridomiciliary $(247 / 297,83 \%)$. L. lenti $(154 / 297,52 \%)$ was the most frequently sampled species, followed by L. longipalpis $(88 / 297,29.6 \%)$, and L. sallesi $(42 / 297,14.1 \%)$, which together accounted for over $90 \%$ of the collected sandfly specimens. Conclusions: The continued presence of $L$. longipalpis in urban areas, including that in intradomiciliary areas, with a predominance of females, is crucial because of the high possibility of them causing VL outbreaks, since this species is the main vector of Leishmania infantum in Brazil.
\end{abstract}

Keywords: Lutzomyia longipalpis. Leishmania infantum. Urbanization.

\section{INTRODUCTION}

Sandflies (Diptera: Psychodidae) are important insects that are widespread globally, with approximately 800 species; there are approximately 243 known sandfly species in Brazil ${ }^{(1)(2)}$. It is known that several species of sandflies are vectors of pathogens, including the Leishmania protozoan (Kinetoplastida: Trypanosomatidae), which is an etiologic agent of leishmaniasis ${ }^{(3)}$. In Brazil, two species are involved in transmission of visceral leishmaniasis (VL), namely Lutzomyia longipalpis and Lutzomyia cruzi ${ }^{(4)}$. Lutzomyia migonei specimens were found to be naturally infected with Leishmania infantum, in São Vicente Ferrer, Pernambuco ${ }^{(5)}$ and Rio de Janeiro $^{(6)}{ }^{(7)}$. An experimental infection with $L$. infantum was reported in a previous study ${ }^{(8)}$. However, further studies are

Corresponding author: Profa. Gílcia Aparecida de Carvalho. e-mail: gilciasilva@yahoo.com.br; rafaelanramos10@yahoo.com.br Received 27 April 2016

Accepted 22 November 2016 needed to elucidate the role of this species in the epidemiology of VL in Brazil.

The occurrence of VL and American cutaneous leishmaniasis (ACL) in the Americas involves complex ecology and epidemiology, because it is directly related to the distribution of the species of sandflies ${ }^{(9)(10)}$. Because of environmental changes resulting from the deforestation and urbanization processes observed in various regions of Brazil, some species of wild sandflies settled around human dwellings and animal shelters, demonstrating their adaptation to the environments modified by humans. This phenomenon contributed to the gradual spread of $\mathrm{VL}$ in all the regions of the State of Pernambuco over the last two decades ${ }^{(5)}$. For example, from 2005 to $201016.9 \%$ of canine visceral leishmaniasis (CVL) was observed in the municipality of Caruaru ${ }^{(11)}$. More recently, in 2015, an outbreak of VL was reported in the same study area, with six human cases ${ }^{(12)}$.

Despite recent progress in mapping the geographical distribution of vector-borne diseases, the occurrence and expansion of VL vectors have not been systematically monitored or documented. This is because of the epidemiological characteristics 
and insufficient knowledge about the various elements involved in the transmission chain of VL in some areas where control strategies are still ineffective. Therefore, for performing surveys on sandflies, an increased familiarity with the areas of occurrence and an understanding of the population dynamics of VL vectors are important factors that can help expand the epidemiological control policies. The aim of the present study was to identify different species that constitute the sandfly fauna in a specific urban area in northeastern Brazil where VL cases have been reported.

\section{METHODS}

\section{Study area}

The study was conducted in the municipality of Caruaru $\left(08^{\circ} 16^{\prime} 58^{\prime \prime}\right.$ South and 35 58'33" West), which has an estimated population of 351,686 people and is considered an urban VL endemic area in the State of Pernambuco, Northeastern Brazil.

Over the recent years, the municipality has grown inordinately, presenting a close interface between the urban and rural areas. The main economic activity of the area is textile production, followed by subsistence agriculture ${ }^{(13)}$. It has a semi-arid climate with winter rainfall. Its pluviometric index is approximately $662 \mathrm{~mm}$, unevenly distributed throughout the year. The average annual temperature is $22.5^{\circ} \mathrm{C}$, and the annual average of relative humidity $(\mathrm{RH})$ is $75 \%$. The predominant vegetation is Caatinga, with the presence of some remnant Atlantic Rainforest. The climatic data on temperature, $\mathrm{RH}$, and rainfall were recorded by the Agronomic Institute of Pernambuco [Instituto Agronômico de Pernambuco (IPA)] and the Pernambuco Agency for Water and Climate [Agência Pernambucana de Águas e Clima (APAC)].

\section{Collection and identification of sandflies}

From November 2014 to December 2015, samples were collected from five districts in the municipality of Caruaru: Morada Nova, Rendeiras, Campo Novo, Nova Caruaru, and Alto do Moura. The criteria for selection of the capture sites were based on the occurrence of human and/or canine VL cases ${ }^{(12)}$, as well as on the presence of dogs and/or other pets in homes.

The capture of insects was performed monthly for three consecutive nights. Twelve Centers for Disease Control (CDC) light traps ${ }^{(14)}$ were placed in each of the districts, $1.5 \mathrm{~m}$ above the ground level, in the evening (at 5:00pm) and gathered at dawn (at 6:00am). The traps were placed in different intradomicile and peridomicile ecotypes: sheepfold, pen, kennel, barn, chicken coop, and pigsty. Households with traps were georeferenced; each trap was numbered and mapped using satellite remote sensing global positioning system (GPS).

The collected insects were fixed in 70\% alcohol and identified using taxonomic keys ${ }^{(15)}$.

\section{Data analysis}

The data were submitted for descriptive statistical analysis. The Lilliefors test was used to verify the normality of the data. The relationship between the number of collected sandflies and climatic variables was measured using cross correlation coefficient and $t$-test ${ }^{(16)}$. The Friedman test was used to compare the monthly variation in species among the collected sandflies. The Chi-square test $\left(\chi^{2}\right)$ with Yates correction was used to compare the presence of males and females in the environment (intradomiciliary or peridomiciliary), as well as the occurrence of various sandfly species in the different ecotypes. A $5 \%$ significance level was considered. The BioEstat software version 5.3 was used for statistical calculations ${ }^{(17)}$.

\section{RESULTS}

A total of 297 sandflies were collected during the study, of which 122 (41\%) were males and 175 (59\%) were females; i.e., a sex ratio $(\mathrm{M}: \mathrm{F})$ of $1: 1.43$. No monthly statistical difference between the number of collected females and males was observed $(\mathrm{Fr}=0.0714 ; \mathrm{p}=0.7893)$.

Eight species were identified (Table 1), and Lutzomyia lenti was the species that was collected most often $(154 / 297,52 \%)$,

TABLE 1

Sandfly species collected in an urban area of Caruaru, State of Pernambuco, from November 2014 to December 2015.

\begin{tabular}{|c|c|c|c|c|c|}
\hline & & Males & Females & Intradomicile & Peridomicile \\
\hline L. lenti (Mangabeira, 1938) & 154 & $55(35.7)$ & $99(64.3)$ & $21(13.6)$ & $133(86.4)$ \\
\hline L. longipalpis (Lutz \& Neiva, 1912) & 88 & $40(45.4)$ & $48(54.5)$ & $15(17.0)$ & $73(83.0)$ \\
\hline L. sallesi (Galvão e Coutinho, 1939) & 42 & $21(50.0)$ & $21(50.0)$ & $10(24.0)$ & $32(76.0)$ \\
\hline L. walkeri (Newstead, 1914) & 3 & - & $3(100.0)$ & -- & $3(100.0)$ \\
\hline L. capixaba (Dias, Falcão, Silva \& Martins, 1987) & 3 & $1(33.3)$ & $2(66.7)$ & $3(100.0)$ & -- \\
\hline L. carmelinoi (Ryan, Fraihab \& Brazil, 2001) & 2 & -- & $2(100.0)$ & -- & $2(100.0)$ \\
\hline L. whitmani (Antunes \& Coutinho, 1939) & 1 & $1(100.0)$ & -- & $1(100.0)$ & - - \\
\hline
\end{tabular}

L.: Lutzomyia. 
followed by L. longipalpis (88/297, 29.6\%) and Lutzomyia sallesi (42/297, 14.1\%), which together accounted for more than $90 \%$ of the collected sandflies. L. lenti, L. longipalpis, and $L$. sallesi were the most commonly occurring species throughout the study, with monthly variations (Friedman test, $\mathrm{p}=0.0429$ ). It is important to note that $L$. longipalpis was more predominant in June $(\mathrm{n}=16)$ and $L$. lenti was more frequently found in July $2015(\mathrm{n}=36)$. These three species were found in all the surveyed neighborhoods.

The sandflies showed preference for peridomicile environments (247/297, 83\%), followed by dwellings (50/297, $17 \%)$. Both males and females were abundant in animal sheds $(105 / 247,42.5 \% ; 142 / 247,57.5 \%$, respectively), and no statistical difference between them was observed $\left(\chi^{2}=0.917\right.$; $\mathrm{p}=0.3381$ ).

Lutzomyia longipalpis $(73 / 247,29.6 \%)$ and L. lenti $(133 / 247,54 \%)$ were captured mainly in animal sheds and no statistical difference was observed between them $\left(\chi^{2}=0.514\right.$; $\mathrm{p}=0.5967)$. It is important to note that $L$. longipalpis females $(9 / 48,18.7 \%)$ were collected from bedrooms of the houses.

When observing the preference of sandflies to the peridomicile ecotypes, the study found a high prevalence in chicken coops, followed by kennels, sheepfolds, pigsties, barns, and stalls. L. longipalpis was mainly detected in chicken breeding sites $(34 / 73,46.6 \%)$ and $L$. lenti was detected in sheepfold $(51 / 132,38.6 \%)$.

The species were more abundant in May and July 2015, at average temperatures 25.1 and $21.9^{\circ} \mathrm{C}$ and $\mathrm{RH} 66$ and $81 \%$, respectively. However, in the present study any influence of temperature on the number of sandflies was observed through the analysis of cross correlation coefficient (cross correlation coefficient $=-0.21$; Figure 1). Moreover, RH directly influenced the number of specimens collected (cross correlation coefficient $=-0.53$ ). The rainfall ranged from 0.0 (December 2014) to $118.7 \mathrm{~mm}$ (June 2015). No significant $(\mathrm{p}>0.05)$ correlation between the number of samples collected per month and precipitation was observed (cross correlation coefficient $=0.21$ ).

\section{DISCUSSION}

The present study identified the sandfly fauna in an urban area, endemic for VL, located in the Northeast of Brazil. The presence of some species of sandflies in urban areas confirms the ability of these insects to adapt to environments with profound

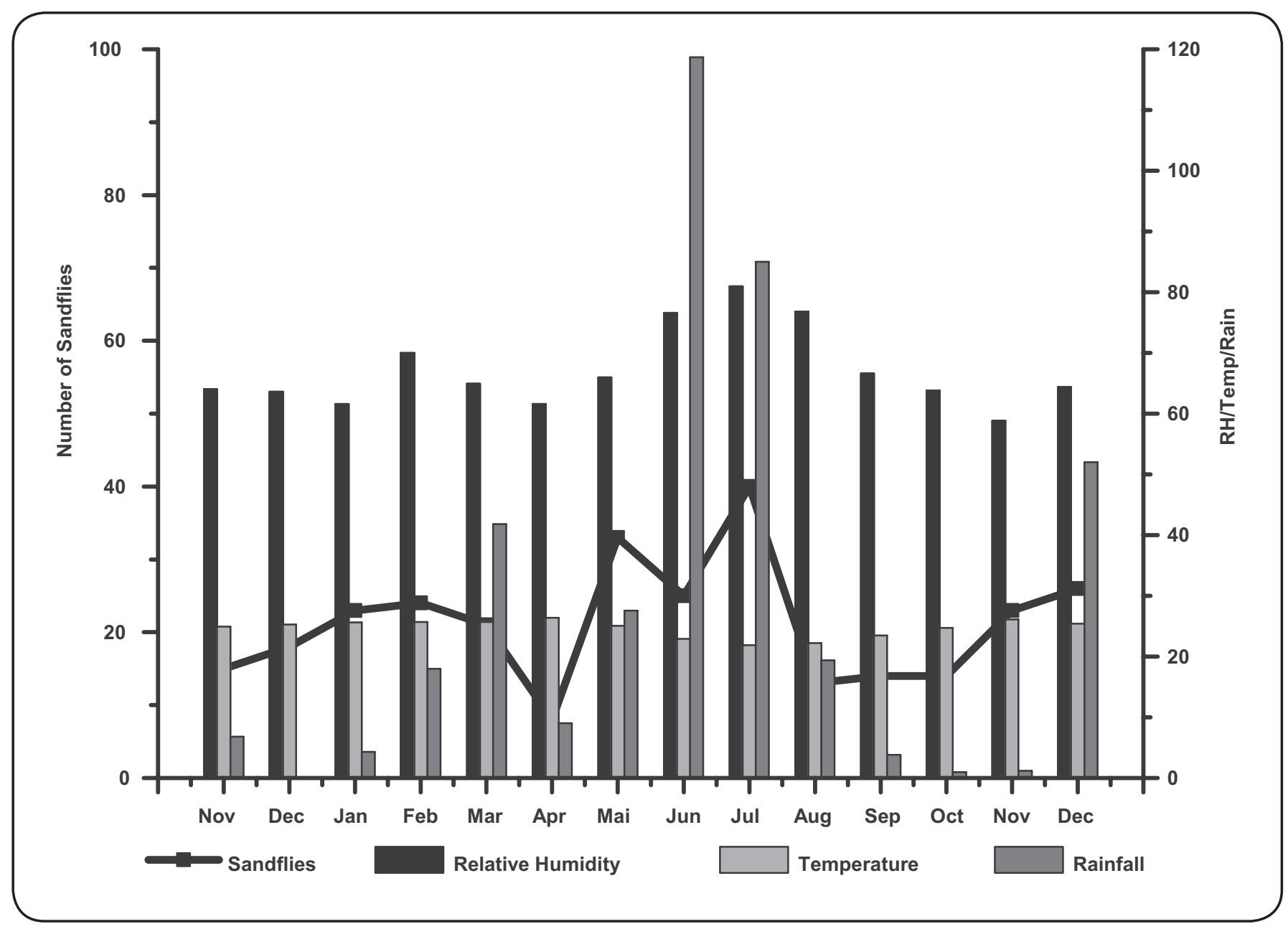

FIGURE 1. Number of sandflies collected and climatic variations in Caruaru, State of Pernambuco, from November 2014 to December 2015. RH: relative humidity. 
difference from their natural habitats ${ }^{(18)}$. Three sandfly species, L. lenti, L. longipalpis, and L. sallesi were found in all the surveyed neighborhoods. From an epidemiological perspective, this finding is very important because of the spread of insects in the city, especially L. longipalpis, which is considered the main vector of $L$. infantum in Brazil.

Most (247; 83\%) sandflies collected during the study period were peridomiciliary. An increase in the abundance and diversity of peridomiciliary sandflies has been observed in several areas of Brazil in recent years ${ }^{(5)}$. It is important to correlate the vector density with favorable environmental aspects for peridomiciliary sandflies, such as the presence of vegetation, roots, tree trunks, and organic matter, which are the possible shelters and breeding grounds for the vector ${ }^{(19)}$. In locations, from where the samples were collected, there were mostly poor households, with deficient basic sanitation and high pet population, resulting in the accumulation of organic matter. The families maintained diverse types of animal breeding outside their houses as means of subsistence. These conditions were more pronounced in places like Alto do Moura and Nova Caruaru, where a higher frequency of sandflies was found. These environmental factors associated with low economic status of residents have been reported to contribute considerably to the transmission of $\mathrm{VL}^{(20)}$.

Lutzomyia lenti represented $51.8 \%$ of the captured sandflies. This finding is notable, given the fact that this species feeds on the blood of humans, horses, and dogs. It has wide distribution in the country and although it is not presumably a vector of Leishmania, it is found in ACL and VL transmission areas ${ }^{(21)}$. L. lenti was found naturally infected with promastigotes in the City of Jacobina, Bahia ${ }^{(22)}$. Therefore, the possible epidemiological role of $L$. lenti needs to be further clarified.

Lutzomyia longipalpis is the main vector of $L$. infantum in the New World. This species represented $29.6 \%$ of the specimens captured in this study. It is possible that this species is more adaptive to the environmental changes than the other Lutzomyia spp., as it is perpetuated in different ecotypes and is most synanthropic (23) (24). This species was collected in large numbers from chicken coops, pigsties, and corrals. In fact, it is known that chickens are among the preferred hosts for the blood meal of L. longipalpis ${ }^{(20)(26)}$.

Lutzomyia sallesi represented $14.1 \%$ of the sandflies collected during the study period. This species commonly spread in the State of Minas Gerais and has been found naturally infected with L. infantum $^{(27)}$. There are no records to date suggesting that this species uses humans as hosts. However, it may be involved in a wild or rural cycle of Leishmania transmission ${ }^{(28)}$.

The species L. migonei, L. walkeri, L. capixaba, L. whitmani, and $L$. carmelinoi together amounted to $4.37 \%$ of the collected sandflies. L. migonei, although not as anthropophilic as L. intermedia, can reach man and domestic animals by adapting to their home environment. Its presence inside the homes and outdoors indicates its adaptation to human environments ${ }^{(5)}{ }^{(29)}$. L. migonei was found naturally infected in the municipality of São Vicente Ferrer, Pernambuco ${ }^{(5)}$ and in the State of Rio de Janeiro $^{(6)}{ }^{(7)}$. However, its role in the epidemiology of VL in Brazil needs to be elucidated.
Lutzomyia walkeri, Lutzomyia capixaba, and Lutzomyia carmelinoi are usually found in forest environments, probably because of more abundant resources. However, in this study they were also observed in locations showing effects of human intervention, suggesting some adaptation to the changing environments $^{(5)}$.

Lutzomyia whitmani is well known for its anthropophilic action and involvement in the transmission of leishmaniasis in Brazil and Paraguay(25) (30) (31). The data on the ecology of this species is still incipient, especially in Northeastern Brazil ${ }^{(32)}$. However, even at low density, it may be contributing to the transmission of ACL in the urban area of Caruaru.

The seasonal dynamics of sandflies can vary greatly from region to region, and the varying climatic factors, over time, might cause species to have different patterns in the same geographical area ${ }^{(5)}(26)$. The specimens collected in this study showed abundance in the months of May and July 2015, corresponding to the months before and after the wettest period of the year. The greatest abundance of sandflies occurred in June 2015, the month with the highest rainfall of the year; this pattern was also observed in several other regions of Brazil ${ }^{(18)}$. The present study showed a moderate positive correlation between the number of sandflies and rainfall, but no significant correlation could be deduced. On the other hand, a negative correlation was observed, with direct influence between the number of insects and humidity. Finally, a negative, albeit non-significant, correlation between the number of sandflies and temperature was observed.

This study provides additional data on the ecology of the sandfly, L. longipalpis, which is the main vector of L. infantum in South America. Moreover, the study demonstrated the ability of this species to adapt to anthropic environments. This species was consistently present in the studied locations and showed general intradomicile adaptation in the urban areas, which suggest a high possibility of VL outbreaks in these environments. The rainy season presented the highest risk, since it was the period showing the highest occurrence of the vector. The role of other sandfly species in the epidemiology of VL in Brazil needs to be elucidated in future studies.

\section{Acknowledgments}

The authors would like to thank the Secretaria Municipal de Saúde de Caruaru, IV Gerência Regional de Saúde, Secretaria Estadual de Saúde and Fundação Nacional de Saúde for supporting this study.

\section{Conflict of interest}

The authors declare that there is no conflict of interest.

\section{REFERENCES}

1. Galati EAB. Classificação de Phlebotominae. In: Rangel ER, Lainson R, editors. Flebotomíneos do Brasil. Rio de Janeiro: Fiocruz; 2003. p. 23-51.

2. Aguiar GM, Medeiros WM. Distribuição regional e habitats das espécies de flebotomíneos do Brasil. In: Flebotomíneos do Brasil. Rio de Janeiro: Fiocruz; 2003. p. 207-255. 
3. Maroli M, Feliciangeli MD, Bichaud L, Charrel RN, Gradoni L. Phlebotomine sandflies and the spreading of leishmaniases and other diseases of public health concern. Med Vet Entomol 2013; 27 : 123-147.

4. Ministério da Saúde. Secretaria de Vigilância em Saúde. Departamento de Vigilância Epidemiológica. Manual de Vigilância e Controle da Leishmaniose Visceral. (Série A. Normas e Manuais Técnicos); Brasília: Editora do Ministério da Saúde; 2003. 120p.

5. Guimarães VCFV, Costa PL, Silva FJ, Silva KT, Silva KG, Araújo AIF, et al. Phlebotomine sandflies (Diptera: Psychodidae) in São Vicente Férrer, a sympatric area to cutaneous and visceral leishmaniasis in the State of Pernambuco, Brazil. Rev Soc Bras Med Trop 2012; 45:66-70.

6. Pita-Pereira D, Alves CR, Souza MB, Brazil RP, Bertho AL, Barbosa FA, et. al. Identification of naturally infected Lutzomyia intermedia and Lutzomyia migonei with Leishmania (Viannia) braziliensis in Rio de Janeiro (Brazil) revealed by a PCR multiplex non-isotopic hybridisation assay. Trans R Soc Trop Med Hyg 2005; 99:905-913.

7. Carvalho BM, Maximo M, Costa WA, Santana ALF, Costa SM, Rego TANC, et. al. Leishmaniasis transmission in an ecotourism area: potential vectors in Ilha Grande, Rio de Janeiro State, Brazil. Parasit Vectors 2013; 6:325.

8. Guimarães VCFV, Pruzinova K, Sadlova J, Volfova V, Myskova J, Brandão-Filho SP, et al. Lutzomyia migonei is a permissive vector competent for Leishmania infantum. Parasit Vectors 2016; 9:159.

9. Sharma U, Singh S. Insect vectors of Leishmania: distribution, physiology and their control. J Vector Borne Dis 2008; 45:255-272.

10. Carvalho SMS, Santos PRB, Lanza H, Brandão-Filho SP. Diversidade de flebotomíneos no Município de Ilhéus, Bahia. Epidemiol Serv Saúde 2010; 19:239-244.

11. Souza ZC, Brandespim DF, Agra MCR, Simões-Mattos L. Leishmaniose visceral canina e humana em Caruaru, Pernambuco, no período de 2005 a 2010. Rev Patol Trop 2014; 43:57-68.

12. Secretaria Municipal de Saúde de Caruaru. 2015. Boletim da Saúde 2013. Acessado: 13/12/2015. Disponível em: http://www. saudecaruaru.pe.gov.br/smscaruaru2013/index.php/

13. Instituto Brasileiro de Geografia e Estatística (IBGE). Cidades@. 2016. Acessado: 02/02/2016. Disponível em: http://cidades. ibge.gov.br/xtras/perfil.php?lang=\&codmun $=\quad$ 260410\&search $=$ pernambuco|caruaru

14. Sudia WD, Chamberlain RW. Battery operated light trap, an improved model. Mosquito News 1962; 22:126-129.

15. Young DG, Duncan MA. Guide to the identification and geographic distribution of Lutzomyia sand flies in Mexico, the West Indies, Central and South America (Diptera: Psychodidae). Mem American Entomol Inst 1994; 54:1-881.

16. Box GEP, Jenkins GM, Reinsel GC. Time Series Analysis: Forecasting and Control. $4^{\text {th }}$ edition. New Jersey: Wiley; 2008; 784p.

17. Ayres M, Ayres Jr M, Ayres DL, Santos AL. BioEstat 2.0: Aplicações estatísticas nas áreas das ciências biológicas e médicas. Belém, Sociedade Civil Mamirauá. Brasília: CNPq; 2000. 272p.

18. Almeida PS, Minzão ER, Minzão LD, Silva SR, Ferreira AD, Faccenda O, et al. Aspectos ecológicos de flebotomíneos (Diptera: Psychodidae) em área urbana do município de Ponta Porã, Estado de Mato Grosso do Sul. Rev Soc Bras Med Trop 2010; 43:723-727.
19. Camargo-Neves VLF, Katz G, Rodas LAC, Poletto DW, Lage LC, Spínola RMF, et al. Utilização de ferramentas de análise espacial na vigilância epidemiológica de leishmaniose visceral americana Araçatuba, São Paulo, Brasil, 1998-1999. Cad Saude Publica 2001; 17:1263-1267.

20. Barata RA, França-Silva JC, Mayrink W, Silva JC, Prata A, Lorosa ES, et. al. Aspectos da ecologia e do comportamento de flebotomíneos em área endêmica de leishmaniose visceral, Minas Gerais. Rev Soc Bras Med Trop 2005; 38:421-425.

21. Brazil RP, Carneiro VL, Andrade Filho JD, Alves JCM, Falcão AL. Biology of Lutzomyia lenti (Mangabeira) (Diptera: Psychodidae). An Soc Entomol Bras 1997; 26:191-193.

22. Sherlock IA. Ecological interactions of visceral leishmaniasis in the State of Bahia, Brazil. Mem Inst Oswaldo Cruz 1996; 91:671-683.

23. Scandar SAS, Silva RAD, Cardoso-Júnior RP, Oliveira FH. Ocorrência de leishmaniose visceral americana na região de São José do Rio Preto, estado de São Paulo, Brasil. BEPA. Bolet Epid Paul (Online) 2011; 8:13-22.

24. Dantas-Torres F, Solano-Gallego L, Baneth G, Ribeiro VM, de Paiva-Cavalcanti M, Otranto D. Canine leshmaniosis in the Old and New Worlds: unveiled similarities and diferences. Trends Parasitol 2012; 28:531-538.

25. Nunes VLB, Galati EAB, Cardozo C, Rocca MEG, Andrade ARO, Santos MFC, et. al. Estudo de flebotomíneos (Diptera, Psychodidae) em área urbana do município de Bonito, Mato Grosso do Sul, Brasil. Rev Bras Entomol 2008; 52:446-451.

26. Costa PL, Dantas-Torres F, da Silva FJ, Guimarães VCFV, Gaudêncio K, Brandão-Filho SP. Ecology of Lutzomyia longipalpis in an area of visceral leishmaniasis transmission in north-eastern Brazil. Acta Tropica 2013; 126:99-102.

27. Nascimento BWL, Saraiva L, Teixeira Neto RG, Serra e Meira PCL, Sanguinette CC, Tonelli GB, et al. Study of sand flies (Diptera: Psychodidade) in visceral and cutaneous leishmaniasis areas in central western of Minas Gerais state - Brazil. Acta Tropica 2013; 125:262-268.

28. Saraiva L, Carvalho GM, Gontijo CM, Quaresma PF, Lima AC, Falcão AL, et. al. Natural infection of Lutzomyia neivai and Lutzomyia sallesi (Diptera: Psychodidae) by Leishmania infantum chagasi in Brazil. J Med Entomol 2009; 46:1159-1163.

29. Aguiar GM, Medeiros WM, Marco TS, Santos SC, Gambardella S. Ecologia dos flebotomíneos da Serra do Mar, Itaguaí, Estado do Rio de Janeiro, Brasil. I - A fauna flebotomínica e prevalência pelo local e tipo de captura (Diptera, Psychodidae, Phlebotominae). Cad Saude Publica 1996; 12:195-206.

30. Galati EAB, Nunes VLB, Dorval MEC, Oshiro ET, Cristaldo G, Espíndola MA, et. al. Estudo dos flebotomíneos (Diptera, Pychodidae), em área de leishmaniose tegumentar, no Estado de Mato Grosso do Sul, Brasil. Rev Saúde Pública 1996; 30: 115-128.

31. Lainson R, Shaw JJ. New world leishmaniasis. In: Topley and Wilson's Microbiology and Microbial Infections. Boston: Hodder Arnold; 2005 .

32. Miranda DEO, Sales KGS, Faustino MAG, Alves LC, Brandão-Filho SP, Dantas-Torres F, et. al. Ecology of sand flies in a low-density residential rural area, with mixed forest/ agricultural exploitation, in north-eastern Brazil. Acta Trop 2015; 146:89-94. 